\title{
Communicative challenges in assessing progress towards environmental quality objectives
}

\author{
Victoria Wibeck
}

\begin{abstract}
Assessment of trends in the state of the environment constitutes one important aspect of efforts to achieve environmental sustainability. Assessments are often undertaken via indicators which measure progress towards environmental objectives and interim targets. This paper starts from the assumption that different types of environmental indicators have different implications for the public communication and the societal dialogue about the state of the environment and the measures needed to increase ecological sustainability.

The paper concludes that it is important to evaluate environmental indicators on the basis of their communicative potential. It is demonstrated how science-based assessment of progress towards environmental objectives may fulfil different aims. Each of these aims may be linked to particular types of indicators, as well as to particular ideas of how to communicate uncertainties, and to particular views of the role of the public in the system of environmental objectives.
\end{abstract}

\section{Introduction}

Today's environmental problems, such as eutrophication, acidification, and global climate change, seriously affect peoples' life conditions and challenge local, regional, national, and international institutions. Since these problems know no regional or national borders, they require cooperation between many actors, operating simultaneously on multiple scales in different policy domains [1-4]. Moreover, calls for public participation in handling environmental problems are increasingly heard from scientists and policy-makers $[5,6]$. This implies that science-based ideas of how to achieve ecological sustainability and measure progress towards a better environment must be communicated within and across the boundaries of society's various sectors as well as to the general public [cf. 7].

One important aspect of the efforts to achieve environmental sustainability is the assessment of trends in the state of the environment. Such assessments are often carried out with the help of indicators, which should mirror changes in the environment [8]. ${ }^{1}$ From the results of science-based assessments, policy makers could decide on new environmental objectives, targets and measures. Assessment results could also result in lay people and NGOs taking action to change unsustainable lifestyles etc. This paper starts from the assumption that different types of indicators have different implications for the public communication and the societal dialogue about the state of the environment and the measures needed to increase ecological sustainability. I argue that there is a need for actors involved in environmental science, policy and management to reflect upon how the choice of particular indicators influences the societal dialogue on science-based environmental policies and measures.

This paper will take its point of departure in the Swedish system of national environmental quality objectives. It will discuss how assessment activities may seek to fulfil several different aims, and how indicators for assessment could be used as communicative tools addressing different target groups in different ways. The paper will first analyze different types of aims attributed to the assessment which were found in Government Bills and in interviews with key actors in the Swedish environmental bureaucracy.

\footnotetext{
${ }^{11}$ An example of the use of environmental indicators could be taken from the Swedish system of national environmental quality objectives. For the objective Zero eutrophication, goal achievement is assessed by measuring nitric oxide emissions, ammonia emissions, phosphorous in the sea, nitrogen in the sea, phosphorous entering coastal areas, nitrogen entering coastal areas, acreage of catch crops, acreage of protection zones, and per capita driving distance by car.
} 
Secondly, this analysis will form the basis for a discussion about the implications of using different types of indicators for societal dialogue about environmental goal achievement. However, an introduction to environmental management-by-objectives, in Sweden and elsewhere, will first be provided.

\section{Environmental management by objectives}

The present paper concentrates on a specific technique for public environmental management known as management by objectives (MBO). ${ }^{2}$ In public environmental $\mathrm{MBO}$, politicians determine environmental objectives and interim targets to be implemented and assessed by civil servants in national, regional, and local contexts [9]. In environmental $\mathrm{MBO}$, scientific knowledge is indispensable in identifying environmental threats and formulating environmental objectives and targets. Furthermore, efforts to monitor and assess environmental trends rely heavily on scientific knowledge of ecological systems and how they interact and change, and on statistical methods for analysing and evaluating data.

This paper focuses on the Swedish system of national environmental quality objectives. In Sweden, often cited as a leader in environmental policy and implementation [e.g., 4, 10, 11], efforts to achieve sustainability have been channelled through sixteen national environmental quality objectives to be achieved within one generation (table 1). The objectives are specified through interim targets, which focus on concrete environmental measures, assessable in the short and long terms [12]. In the assessment process scientists and other experts in the environmental administration supply science-based knowledge of changes in trends captured by environmental indicators. This information is evaluated by civil servants at state agencies and subsequently communicated to policy makers. Indicators are selected according to the DPSIR model (Driving forces, Pressure, State, Impact, Response) developed by the OECD [13]. This means that for each objective, there should be an appropriate mix of indicators which should mirror different aspects of the DPSIR model [9].

The assessment results form the basis of political decisions as to whether to include new objectives or interim targets, or to keep or change existing ones. Moreover, progress towards environmental objectives is communicated to a wider audience via written reports, the mass media, and a public Internet portal in order to encourage more environmentally friendly lifestyles and consumption patterns. Thus, one type of science communication takes place between scientists and civil servants exchanging information about the results of assessing changes in environmental indicators, the methodologies used to achieve the results, and the uncertainties affecting interpretations of the results. Another type of science communication occurs when the results of assessment of progress towards environmental objectives are presented in reports authored by civil servants to members of parliament and the government. A third type of communication occurs when assessment results are presented to the public mainly by journalists/science writers.

\begin{tabular}{|l|l|l|l|}
\hline 1. & Reduced climate impact & 9. & Good-quality groundwater \\
\hline 2. & Clean air & 10. & $\begin{array}{l}\text { A balanced marine environment, } \\
\text { flourishing coastal areas and archipelagos }\end{array}$ \\
\hline 3. & Natural acidification only & 11. & Thriving wetlands \\
\hline 4. & A non-toxic environment & 12. & Sustainable forests \\
\hline 5. & A protective ozone layer & 13. & A varied agricultural landscape \\
\hline 6. & A safe radiation environment & 14. & A magnificent mountain landscape \\
\hline 7. & Zero eutrophication & 15. & A good built environment \\
\hline 8. & Flourishing lakes and streams & 16. & A rich diversity of plant and animal life \\
\hline
\end{tabular}

Table 1. The Swedish environmental quality objectives.

Earlier studies of the Swedish system of environmental objectives [14, 15] have shown that in assessing environmental goal achievement, various actors have divergent understandings of questions as basic as: Why should assessment be undertaken? What should be assessed? How should assessment be done? Who should undertake the assessments and communicate the results, and to whom should assessment results be communicated? This is probably typical when vaguely formulated objectives are implemented in large

\footnotetext{
${ }^{2}$ Examples of countries using an MBO system for public environmental management include Sweden, Finland, the Netherlands, Germany, the United Kingdom, Canada, and Australia.
} 
organizations where actors change over time [16]. Although these questions were thought through and communicated at the launch of the MBO system, they must be kept alive by being discussed and rethought repeatedly. In this paper, I concentrate especially on the why and what questions above, analyzing how the Swedish Government Bills on the environmental objectives present the aims of assessment and how these aims are addressed via a selection of indicators. I also analyze interview data to identify aims attributed to assessment by the respondents.

\section{Methods}

Three Swedish Government Bills on the environmental objectives have been published so far $[12,17$, 18]. For the purposes of this paper, these bills were analysed by means of quantitative content analysis [19]. All text segments which mentioned aims of the assessment were identified. These segments were subsequently coded and categorized. To ensure reliability, this procedure was undertaken independently by two researchers. Thereafter, a qualitative content analysis was pursued, in which the identified text segments were additionally analysed and interpreted [cf. 20].

The analyses presented here are also based on data from in-depth interviews and focus groups with civil servants in the Swedish environmental administration and with scientists providing statistical tools and methods for assessing environmental goal achievement. Qualitative interviewing was chosen, since this lets informants elaborate their arguments, and express paradoxes and ambivalence [21, 22]. The informants were selected either because the official internet portal for the Swedish environmental objectives (www.miljomal.nu) identified them as key actors in the production, selection, and/or communication of tools and methods for assessing goal achievement, or because they were acknowledged as experts in one or several of these fields by other interviewees [cf. 23]. In total, 15 interviewees participated in the study (table 2).

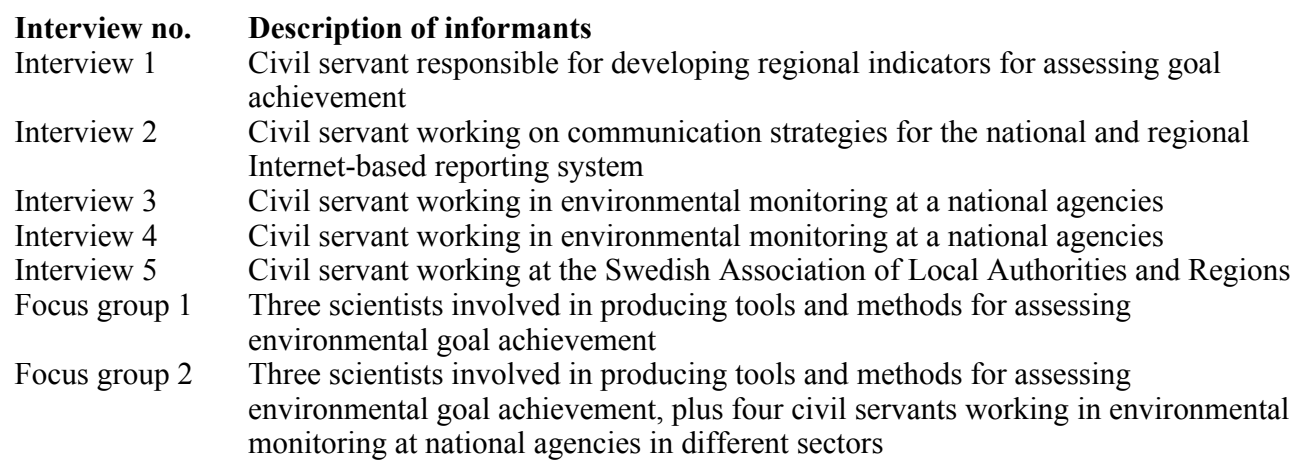

Table 2. Overview of the empirical material.

The interviews and focus group discussions were semi-structured. They lasted 60-90 minutes and were tape-recorded and transcribed. The analytical procedure entailed a thematic content analysis where the data were coded and categorized, and recurrent themes identified [24]. Themes related to the use of indicators and the communication of assessment results were selected for more detailed analysis here. The results of the text analysis as well as the analysis of the interview data will be discussed and interpreted in light of literature from the fields of science communication and environmental management.

\section{Different aims related to the assessment of environmental goal achievement}

From the Government Bills and the interview data analyzed for this paper, it was evident that all key actors agree that assessment is an essential part of environmental management-by-objectives. However, there was no consensus about why this is important. When scrutinizing the data, several different aims were found. The analysis of the three Government Bills $[12,17,18]$ identified a total of 49 text segments related to the purpose of assessment activities. A deeper analysis of these 49 text segments revealed 19 different aims, which recurred in the data (figure 1). The most commonly stated aim was to control trends 
in the state of the environment (aim A). Related to this was the aim of controlling the efficiency of measures and action strategies (aim H). However, the Bills also emphasized e.g. the importance of assessment activities to identify causes of shifts in trends in the state of the environment (aim K) and to create a system of 'early warning', which may predict future environmental problems (aim L).

In the interview and focus group data, the interviewees also discussed different potential aims of assessment. This occurred at 39 different instances in the data. In total, 19 different aims were identified in the interview and focus group data (figure 1). Some of these aims could also be found in the Government Bills, while a few of the aims were only brought up in the interviews. Like the Government Bills, the focus group and interview data displayed a strong focus on the aim to control trends in the state of the environment (aim A). Nevertheless, the interviewees also often emphasised the importance of selecting indicators for assessment that may serve as communicative tools, i.e. indicators that could motivate actors to take action towards a better environment (aim V). The interviewees also pinpointed that the assessment activities could be used as a tool in the environmental bureaucracy, e.g. to form the basis of regional comparisons (aim Q), to identify relevant action strategies (aim U) or to serve as a planning tool (aim W).

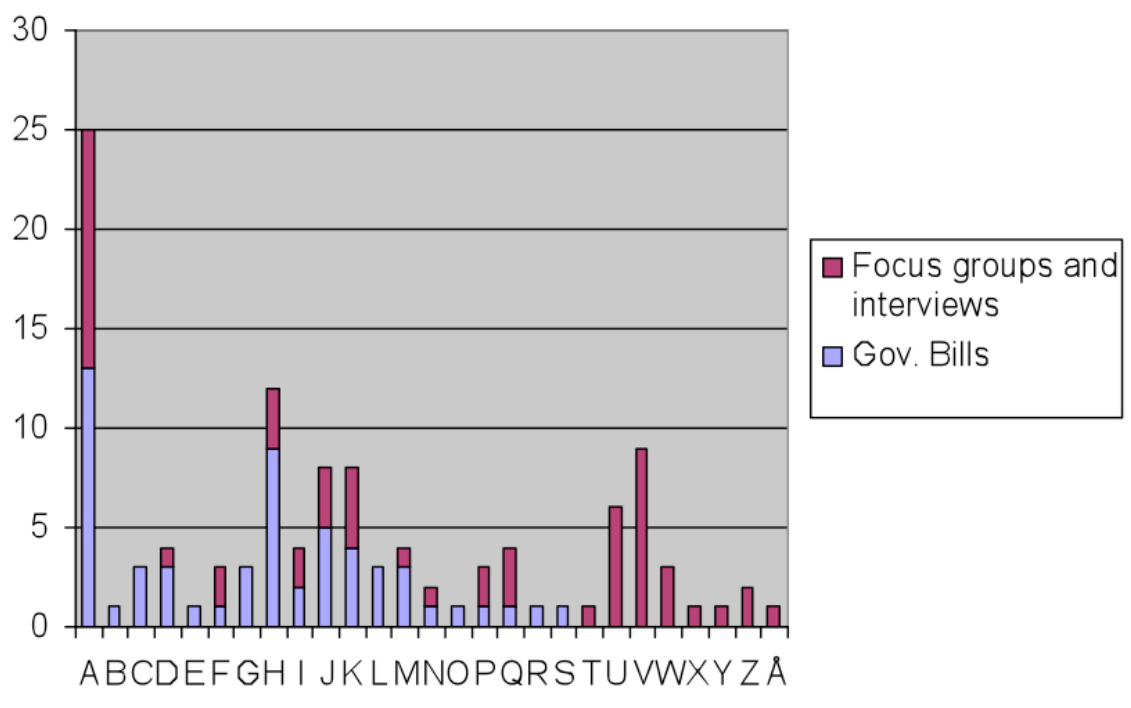

A. Control trends in the state of the environment

B. Account for progress

C. Understand and get an overview of the system environmental objectives

D. Identify internal synergies

E. Identify external synergies

F. Illuminate correlations between particular objectives, interim targets and/ or indicators

G. Revise objectives and interim targets

H. Control efficiency of measures and action strategies

I. Contribute to international assessments

J. "Early warning"

K. Identify underlying causes

L. Control the speed of changes

M. Provide actors with relevant knowledge

N. Provide a basis for making priorities
O. Identify synergies between environmental objectives and other societal objectives

P. Identify relevance for other policy areas

Q. Make regional comparisons

R. Contribute to development

S. Identify environmental 'villains'

T. Identify quality problems in the efforts to achieve the environmental objectives

U. Provide a basis for identifying action strategies

V. Motivate actors to take action

W. Provide a basis for planning

X. Provide pedagogical tools for civil servants

Y. Provide a tool in authorities' superintention activities

Z. Stimulate discussions

A. Bring about results in the efforts to attain the objectives

Figure 1. Aims attributed to the assessment of environmental goal achievement in Government Bills and interview data. 
When further scrutinizing the aims of assessment activities as stated in the Government Bills and the interview data, it was evident that several of the aims were interrelated and could be grouped into broader categories. The list of potential aims found in the data could be reduced into the following comprehensive categories:

- A controlling aim, where the purpose of assessment is to identify whether the trends captured by environmental indicators are positive and fast enough. ${ }^{3}$

- A pedagogical aim, where the purpose of assessment is to present information on the state of the environment to motivate different actors to take action towards more environmentally friendly behaviour, and to create opportunities for dialogue between different actors within the environmental administration. ${ }^{4}$

- A progressive aim, where the purpose of assessment is to influence future action, e.g. by identifying new environmental risks to be incorporated in the system of environmental objectives and interim targets, or to form the basis of the planning instruments used at different agencies and municipalities. ${ }^{5}$

- A reflecting aim, where the purpose of assessment is to deepen the understanding of the system of environmental objectives, e.g. by identifying synergies or conflicts between objectives, between objectives and interim targets, or between environmental objectives and other societal objectives. ${ }^{6}$

- A priority aim, where the purpose of assessment is to get an overview of those environmental issues that are of the highest relevance within the environmental bureaucracy, and to balance different objectives (social, economic and ecological). ${ }^{7}$

- An exploratory aim, where the purpose of assessment is e.g. to identify causes of observed changes in the state of the environment, or to distinguish between anthropogenic and natural changes in environmental trends. ${ }^{8}$

\footnotetext{
${ }^{3}$ The controlling aim could be exemplified by a quote from Government Bill 1997/98: 150 (p. 160): 'Assessments and evaluations bring about a possibility of judging [...] whether we are approaching the environmental objective, or if additional action is needed' (my translation).

${ }^{4}$ The pedagogical aim could be illustrated by the following quotation from an interview with a civil servant at a Swedish County Board: "Among others, we decided to produce an indicator covering the hospitalization of kids due to air pollution in the city ... And that indicator feels important ... it is also a very pedagogical indicator, since even the most indifferent man sitting in his car driving to his technical work can understand that it is not such a good idea to keep building large highways. We have a problem not only with the climate but also with human health'. (Interview 1)

${ }^{5}$ One example illustrating the progressive aim is taken from Government Bill 2004/05:150 (p. 383) that: 'The authorities who have special responsibility for particular environmental objectives should develop a system for capturing and analysing deviant information form the environmental monitoring. The Government has asked the Environmental Protection Agency to develop a warning system to evaluate and manage signals of change which could affect the environment and human health. Other authorities should develop similar warning systems within their own environmental monitoring departments' (my translation).

${ }^{6}$ The reflective aim could be illustrated by the following example from Government Bill 2004/05:145 (pp. 163-164): 'One important issue in the coming years is to get better knowledge on how the results of the measures taken to achieve the four present interim targets contribute to the attainment of the overarching environmental quality objective Sustainable forests. [...] Another dimension concerns how the attainment of interim targets contribute to the attainment of other environmental objectives, such as the objective A rich diversity of plant and animal life, which has been suggested by the Government. [...] Yet a dimension is whether the system of environmental objectives could contribute to attaining objectives in other policy domains, such as forest policy, regional development, cultural policy or public health' (my translation).

${ }^{7}$ The priority aim could be illustrated by the following quote from one of the interviews: 'The most important thing [about the indicators] is to raise discussion of various environmental problems related, for example, to climate change, deforestation, and fish depletion. We assess the trends in these areas with several indicators, and the important thing is to understand that they [the indicators] give us a picture of trends and of what areas to focus on. Then we must start a new discussion about what to prioritize and what measures to take. So the indicators are mainly an excuse for a good discussion. They should give us the basis to see that, okay, here we have a starting point showing us relatively straightforwardly what is happening. Fine, then we have a basis for discussing what measures to take and how to prioritize.'

${ }^{8}$ The exploratory aim could be illustrated by the following quote from a focus group discussion: 'What we look at from the part of Statistics Sweden is not environmental data collected in nature, but it is data from the interface between economic activity and environmental impact. We are interested in analysing other types of trends, for instance finding out... climate variation but also other things such as how market conditions change or prices change. Those are explanations that are important in relation to measures, for instance to decrease carbon dioxide emissions. If consumption increases and people buy products from some place else, emissions will increase despite of the measures taken. These are the types of issues we are working on. We try to find methods to better mirror such correlations.' (Focus group 2).
} 


\section{Implications for the societal dialogue}

In the previous section I outlined six categories of aims that could be fulfilled through the assessment of environmental goal achievement. In the following I will reflect upon each of the aims in turn. For an overview of the different aims and their implications, see table 3. My reflections start from the assumption that each of the different aims identified in the Swedish Government Bills and interview data on the environmental quality objectives have different implications in terms of how they could bring about societal dialogue. For instance, while the controlling aim, the pedagogical aim and - to some extent - the progressive aim are described in the data as involving communication with the general public, the other aims are mainly claimed to facilitate efforts within the environmental bureaucracy to attain the objectives. Nevertheless, as argued below, there could be reason to discuss public communication also in relation to the priority aim and the exploratory aim.

\begin{tabular}{|l|l|l|l|l|}
\hline Aim & $\begin{array}{l}\text { Main target group } \\
\text { for communication }\end{array}$ & $\begin{array}{l}\text { View of the } \\
\text { public }\end{array}$ & $\begin{array}{l}\text { Model for } \\
\text { communicating } \\
\text { uncertainty }\end{array}$ & $\begin{array}{l}\text { Privileged type } \\
\text { of indicators }\end{array}$ \\
\hline Controlling & $\begin{array}{l}\text { Environmental } \\
\text { bureaucracy; policy } \\
\text { makers }\end{array}$ & $\begin{array}{l}\text { Passive } \\
\text { recipients or } \\
\text { active co- } \\
\text { constructors }\end{array}$ & $\begin{array}{l}\text { Separation or } \\
\text { integration } \\
\text { model }\end{array}$ & $\begin{array}{l}\text { Natural science-based; } \\
\text { measurable }\end{array}$ \\
\hline Pedagogical & "Everybody" & $\begin{array}{l}\text { Active co- } \\
\text { constructors }\end{array}$ & $\begin{array}{l}\text { Integration } \\
\text { model }\end{array}$ & $\begin{array}{l}\text { High communicative value; } \\
\text { motivating to action }\end{array}$ \\
\hline Progressive & $\begin{array}{l}\text { Environmental } \\
\text { bureaucracy; policy } \\
\text { makers (and the public) }\end{array}$ & $\begin{array}{l}\text { Active co- } \\
\text { constructors }\end{array}$ & $\begin{array}{l}\text { Separation or } \\
\text { integration } \\
\text { model }\end{array}$ & $\begin{array}{l}\text { Directed to the identification } \\
\text { of changes in environmental } \\
\text { trends which could be an } \\
\text { indication of new } \\
\text { environmental threats }\end{array}$ \\
\hline Priority & $\begin{array}{l}\text { Environmental } \\
\text { bureaucracy }\end{array}$ & $\begin{array}{l}\text { Environmental } \\
\text { bureaucracy; policy } \\
\text { makers (and the public) }\end{array}$ & $\begin{array}{l}\text { Active co- } \\
\text { constructors }\end{array}$ & $\begin{array}{l}\text { Integration } \\
\text { model } \\
\text { of synergies and conflicts }\end{array}$ \\
\hline Exploratory \\
$\begin{array}{l}\text { Scientists (and } \\
\text { bureaucracy, policy } \\
\text { makers and the public) }\end{array}$ & $\begin{array}{l}\text { Potential co- } \\
\text { constructors? }\end{array}$ & $\begin{array}{l}\text { Directed to the identification } \\
\text { of synergies and conflicts } \\
\text { integration } \\
\text { model }\end{array}$ & $\begin{array}{l}\text { Directed to the analysis of } \\
\text { causes of changes in the } \\
\text { state of the environment }\end{array}$ \\
\hline
\end{tabular}

Table 3. Overview of aims attributed to the assessment of environmental goal achievement and their implications for societal dialogue.

\section{The controlling aim}

The controlling aim is what much MBO literature describes as the main aim of assessment [e.g. 25-27]. In order to control whether or not the objectives will be achieved within the stipulated time frame, the controlling aim privileges natural science-based, measurable indicators that could reflect trends in the state of the environment. The main target group for communicating results would be policy makers, who use the assessment results as a basis for decisions on which objectives to keep, change, omit or add. In the Swedish system of assessment, results are presented in the form of red, yellow or green 'smilies', indicating whether the objectives will be attained within the given time frame, will be attained with additional effort, or will not be attained at all even if extra measures are taken [28]. The results of the assessment are also communicated to the public via media reports. The system of smilies means that complex scientific information is reduced into a simple, clear-cut message, leaving very limited room for communicating the uncertainties inherent in the assessment. ${ }^{9}$ The idea here would be to present a clear

\footnotetext{
${ }^{9}$ Uncertainties may originate from a variety of sources. For instance, uncertainty may originate in incomplete or imperfect data sets, insufficient knowledge about nature/society system dynamics or problems of extrapolating sustainability assessments into the future since assumptions about future societal development and development at the interface between nature and society are inherently uncertain [29].
} 
message to policy makers and the public according to a 'separation model' for communication, which means that the expert arena is separated from other societal arenas in evaluating the scientific uncertainties related to the assessment of whether the objectives will be attained or not [15]. The public and the policy makers are perceived in this model as lacking the time, interest, and knowledge to reflect on the uncertainties involved. Pedagogical skills would thus be required from actors in the expert arena, who need to present a clear message as regards assessment results without going into details related to data uncertainties. However, there are also attempts to incorporate uncertainties in the system of visualizing goal attainment, e.g. by adding evaluations of the certainty of the data underlying the smilies [30]. This means that the communication follows an 'integration model', in which uncertainties and differences in scientific methods and interpretations are transparently discussed in the expert as well as the practitioner and the policy arenas [15]. In this model, lay people will be treated as active coconstructors of knowledge rather than as passive recipients.

\section{The pedagogical aim}

The interviewees in the present study repeatedly emphasized the need for privileging indicators with a high communicative value, rather than those indicators most obviously corresponding to the objectives and targets. This idea reflects a deliberative ideal, where the public is supposed to take active part in the political - and sometimes also scientific - process related to the environmental objectives [cf. 6, 31]. The deliberative model presupposes active lay people, who want to engage in science and policy discussions and to take active part in policy processes. Only when different groups of stakeholders, including the general public, have been properly involved in policy processes are they considered to be legitimate [31]. To fulfil the pedagogical aim those indicators are selected which are perceived to motivate the public and policy makers to take action towards lifestyle changes and to prioritize measures towards the achievement of the environmental objectives.

Deliberative ideas could be seen as drawing on an integration model for communicating uncertainties related to the assessment process and results [15]. According to this model, policy makers and civil servants involved in the system of environmental objectives in different sectors need to be informed not only of the results of relevant assessments, but also of underlying uncertainty and methodological choices, and take part in discussions of how to interpret and handle these uncertainties. In a wider perspective, communicating from the integration model means that also in assessment reports directed to the public, uncertainties should be highlighted. Earlier studies have demonstrated that when it comes to complex issues with no certain answer, openness about uncertainties could help raising public trust in society's institutions [32, 33].

\section{The progressive aim}

The progressive aim implies that indicators are selected according to the principle of 'early warning', i.e. that new environmental threats should be identified as early as possible and incorporated in the system of environmental objectives. The progressive aim is well suited to the organization of the Swedish system for environmental monitoring, with the Environmental Protection Agency as responsible for identifying environmental threats to be dealt with in the system of environmental objectives [34]. Achievements towards the progressive aim should thus be communicated from scientists and civil servants in the environmental bureaucracy to policy makers. This information may subsequently be fed into the formulations of new environmental objectives and interim targets. In this respect, the main target groups for communication would be actors in the environmental bureaucracy and policy makers. However, I argue that indicators fitting the progressive aim could, in an indirect way, also be used as tools for communicating with the public. Media interest in the results of the assessment of progress towards environmental objectives has so far been relatively low, since few changes in the state of the environment are detectable from one year to another [35]. However, stories of new environmental threats are likely to fit the media logic [36]. Increased media attention to the environmental objectives could spur public interest and drive public opinion, which in its turn may influence policy. 


\section{The reflecting aim}

When selecting indicators that correspond to the reflecting aim, the target group would be civil servants in the environmental bureaucracy. Here, the important thing is not to identify indicators which could appeal to a broad audience, but to select those indicators which could support the internal dialogue within the environmental administration. Since the system of environmental objectives should influence all societal sectors [12], there is a need for assessments of whether or not the environmental objectives support other societal objectives, or if there are conflicts between e.g. environmental objectives and objectives related to economic growth and employment. Earlier studies have shown that the Swedish system of environmental objectives tend to be perceived by many of its key actors as a hierarchical system, where actors are located 'up' or 'down', struggling to 'reach out' to actors at other levels of the system [37]. In my view, indicators selected to facilitate reflection on how different objectives and targets are related could be helpful to bridge the gap between actors in different societal sectors, but also between actors located at different administrative levels of the environmental bureaucracy. In this respect, indicators designed to fulfil a reflective aim could serve as important communicative tools in the efforts to integrate environmental policy into other policy areas [cf. 4].

\section{The priority aim}

The priority aim is related to the reflecting aim in the sense that assessments demonstrating conflicts between objectives need to be followed by discussions about how to make priorities between different objectives. Indicators designed to fulfil the reflecting aim could thus also be used to stimulate discussions about priorities within the system of environmental objectives, as well as between environmental objectives and objectives in other policy arenas. The target group for communication is thus broadened to include both civil servants in the environmental administration and policy makers. Moreover, I argue that the target group for the priority aim of assessment could be further extended to include the general public. Since discussions about how to prioritize between different objectives in society concern a large number of stake-holders, including the public, such deliberations could benefit from involving an 'extended peer community' [5] consisting of a variety of social actors.

Communication between civil servants, policy makers and other stake-holders about how to prioritize would in my view benefit from using the integration model for communicating uncertainties stemming from data collection and analysis. It has been noted that failure to properly address such uncertainties may endanger the design and implementation of sustainability measures. The uncertainty of knowledge may also be misused as an argument for politicians to employ a 'wait and see' strategy, thus postponing activities directed towards sustainability. On the other hand, if handled in a wise manner, uncertainty may allow for learning processes and deliberations about how the future could be shaped as well as motivating actors to work according to self-defined goals [29] - in other words, the priority aim could be strengthened by open discussions about the consequences of uncertainties.

\section{The exploratory aim}

The exploratory aim is driven by scientific curiosity, the results of which could be applied in identification and revision of environmental objectives and targets. Here, scientists could identify causes for trends in the state of the environment or try to separate natural causes from anthropogenic ones. They could also scrutinize the validity of long time-series which are used in environmental monitoring [for an example, see e.g. 38]. The main target group for the results of such assessment would be scientists. Hence, discussions about uncertainties with an exploratory aim could mainly be reserved for the scientific community, in line with the separation model for communication. Nevertheless, in the data analysed for this paper, it was apparent that civil servants in the environmental administration could also benefit from the exploratory aim and forward the results of such assessments to policy makers to be incorporated in the formulation of new objectives and policies. In that case, the integration model for communicating uncertainties could be applicable.

It would be fruitful to explore how different stakeholders, including the general public, could be involved in 'upstream' engagement in the formulation and attainment of environmental objectives [cf. 
39]. The 'upstream' approach involves different stakeholders early in the scientific process, which would mean extending the target group for the exploratory aim to include e.g. the general public. According to its proponents, an upstream approach could forge a democratic approach to the governance of science [40]. Upstream dialogue could also enhance trust in the policy-making process and generate better quality outcomes [39]. However, there is also a risk that calls for upstream engagement in science end up as yet an expression of the deficit model of science communication, only with the exception that the focus is moved from a perceived deficit of public understanding of science to a deficit of public engagement with science [39]. Hence, more research is needed on if, when and how it would be fruitful to include the public in the target group for the exploratory aim.

\section{Concluding reflections}

This paper set out to discuss the implications of different aims of assessing progress towards environmental objectives, in terms of how indicators for assessment could be used as communicative tools addressing different target groups in different ways. The Swedish system of environmental quality objectives actualises the importance of reflecting upon how different aims of assessment bring about different opportunities - and constraints - in terms of communication to different target groups. This is a type of analysis, I would argue, that could be undertaken when designing communication strategies in any MBO-system.

In environmental management, indicators are often selected with reference to the DPSIR model, capturing aspects of driving forces, pressure, state, impact and response [13]. However, indicators are powerful communicative tools, highlighting those aspects of an environmental objective where actions will be taken $[41,42]$. Thus, I argue that it is also important to evaluate environmental indicators on the basis of their communicative potential. This paper has demonstrated how science-based assessment of progress towards environmental objectives may fulfil different aims. Each of these aims could be linked to particular types of indicators, as well as to particular ideas of how to communicate uncertainties, and to particular views of the role of the public in the system of environmental objectives. Furthermore, it has been argued that different types of indicators suit different target groups.

It is worth noting that the presence of multiple aims of assessment found in the data was problematized neither in the Government Bills, nor by the interviewees. In my view, this could constitute a problem to successful societal dialogue about environmental policies and measures. Assessment can well serve several purposes simultaneously. Nevertheless, I argue that if this agenda is not clearly communicated and understood by those involved in assessment procedures, assessment could be perceived as expensive and time consuming without adding enough new knowledge (given its perceived aims). This could lead to a loss of commitment from actors in the environmental objectives system, threatening the success of the MBO endeavour [cf. 43-45]. Thus, communicators in an environmental MBO system face the challenges of clarifying parallel assessment aims and the kinds of knowledge and expertise needed to achieve those aims, and of clarifying the kinds of results expected, for example, in terms of controlling progress in the trends captured by environmental indicators or in terms of increased public awareness of environmental issues.

In science communication, there is a current focus on 'dialogue' as key to boosting interest in science and technology [46]. 'Dialogue' is also a key concept in improving environmental policy-making processes by involving multiple stakeholders, including the public, in deliberations about how to achieve a sustainable future [e.g., 6]. One promise of the Swedish system of environmental objectives is claimed to lie in its ambitious goal of integrating lay people and actors in different societal sectors, political parties, and organizational levels of the environmental bureaucracy in efforts to achieve the same objectives [4], objectives based on scientific arguments about what to protect and how. For this to become reality, I argue that it is important that communication strategies be developed in organizations involved in the environmental MBO system, strategies enabling participation and dialogue between lay people, scientists, civil servants, and policy makers in different societal sectors and between actors at different levels of the environmental bureaucracy. I conclude that in the endeavour of developing such communication strategies it could be helpful to systematically analyse the communicative implications of different assessment activities. Paying attention to how different types of indicators suit different aims of assessment, and to which target groups that will be affected by the different types of indicators, could be one way of facilitating the dialogue that is needed to involve as many actors as possible in efforts to achieve a more sustainable future. 


\section{Acknowledgments}

This paper was made possible by a grant from the Swedish Environmental Protection Agency for the research program, Assessment of Environmental Goal Achievement Under Uncertainty (no. I-37-03). The author wishes to thank Professor Per Milberg for contribution to the quantitative text analysis of Government Bills presented in the paper.

\section{Notes and references}

[1] T. McDaniels, H. Longstaff and H. Dowlatabadi (2006), A value-based framework for risk management decisions involving multiple scales: a salmon aquaculture example, Environmental Science and Policy 5, 423-438.

[2] J. Hertin and F. Berkhout (2003), EU environmental policy integration and ecological modernisation: an evaluation of the "Cardiff process", Journal of Environmental Policy and Planning 5(1), 39-56.

[3] W. Lafferty and E. Hovden (2003), Environmental policy integration: towards an analytical framework, Environmental Politics 12, 1-22.

[4] M. Nilsson and K. Eckerberg (eds.) (2007), Environmental Policy Integration in Practice: Shaping Institutions for Learning, Earthscan, London.

[5] S. Funtowicz and J. Ravetz (1999), Post-normal science: environmental policy under conditions of complexity, available at: http://www.nusap.net/sections.php?op=printpage\&artid=13, accessed 1 February 2008.

[6] Council of the European Union (2006), Renewed EU sustainable development strategy, available at http://ec.europa.eu/sustainable/docs/renewed_eu_sds_en.pdf, accessed 10 September 2008.

[7] P. Linell (1998), Approaching Dialogue: Talk, Interaction and Contexts in Dialogical Perspectives, John Benjamins, Amsterdam.

[8] Swedish Environmental Protection Agency (1999), System med indikatorer för nationell uppföljning av miljökvalitetsmålen, Report 5006, Naturvårdsverkets Förlag, Stockholm.

[9] K. Edvardsson (2004), Using goals in environmental management: the Swedish system of environmental objectives, Environmental Management 34, 170-80.

[10] J. Meadowcroft (1999), The politics of sustainable development: emergent arenas and challenges for political science, International Political Science Review 20, 219-237.

[11] R. Wurzel (2002), Environmental Policy-making in BRITAIN, GERMANY and the European Union: The Europeanisation of Air and Water Pollution Control, Manchester University Press, Manchester U.K.

[12] Government Bill 2004/05:150, Svenska miljömål - ett gemensamt uppdrag [The Swedish environmental objectives: a common mission].

[13] OECD, Organisation for economic co-operation and development (2000), Frameworks to Measure Sustainable Development, ISBN 92-64-17191-6

[14] V. Wibeck (2008), Critical questions in the assessment of progress towards environmental quality objectives: the case of 'Zero eutrophication', in B. Frostell, Å. Danielsson, L. Hagberg, B-O. Linnér and E. Lisberg Jensen (eds.), Science for sustainable development - the social challenge with emphasis on conditions for change, Proceedings from the 2nd VHU Conference, Linköping 6-7 September 2007, Uppsala VHU.

[15] V. Wibeck (in press), Communicating uncertainty: Models of communication, and the role of science in assessing progress towards environmental objectives, accepted for publication in Journal of Environmental Policy and Planning.

[16] S. McCool (1996), Searching for sustainability. Paper presented at Global congress on coastal and marine tourism, June 1996, Waikiki, Hawaii, available at http://www.cfc.umt.edu/personnel/smccool/default.htm, accessed 25 Aug 2008.

[17] Government Bill 1997/98:145, Svenska miljömål. Miljöpolitik för ett hållbart Sverige [Swedish environmental quality objectives: an environmental policy for a sustainable Sweden].

[18] Government Bill 2000/01:130, Svenska miljömål, delmål och åtgärdsstrategier [The Swedish environmental objectives: interim targets and action strategies].

[19] R. Weber (1990), Basic content analysis, Sage, London U.K. 
[20] L. Levin (2003), Massmedial gestaltning och vardagsförståelse - Versioner av en arbetsplatsomvandling, Linköping Studies in Arts and Science, 279 (Linköping: Linköpings universitet).

[21] S. Kvale (1996), Interviews: An Introduction to Qualitative Research Interviewing, Thousand Oaks, CA, Sage.

[22] I. Marková, M. Grossen, P. Linell and A. Salazar Orvig (2007), Dialogue in Focus Groups: Exploring Socially Shared Knowledge, Equinox, London U.K.

[23] K. Caelli, J. Downie and T. Caelli (2003), Towards a decision support system for health promotion in nursing, Journal of Advanced Nursing 43, 170-180.

[24] V. Wibeck (2004), Exploring focus groups: analysing focus group data about genetically modified food, in K. Aijmer (ed.), Dialogue Analysis VIII: Understanding and Misunderstanding in Dialogue, Selected papers from the 8th IADA conference, Göteborg, pp. 287-298, Tübingen, Niemeyer, Germany.

[25] B. Rombach (1991), Det går inte att styra med mål! En bok om varför den offentliga sektorns organisation inte kan målstyras, Studentlitteratur, Lund, Sweden.

[26] Swedish Environmental Protection Agency (2002), Internationella indikatorer. En översikt av det internationella arbetet med indikatorer för miljö och hållbar utveckling, Report 5205 (Stockholm, Naturvårdsverkets förlag).

[27] J. Voss, J. Newig, B. Kastens, J. Monstadt and B. Nölting (2007), Steering for sustainable development: a typology of problems and strategies with respect to ambivalence, uncertainty and distributed power, Journal of Environmental Policy and Planning 9, 193-212.

[28] Swedish Environmental Objectives Council, http:/www.miljomal.nu/english/english.php, accessed 1 Sept. 2008, The official internet portal for information on the environmental objectives.

[29] A. Grunwald (2007), Working towards sustainable development in the face of uncertainty and incomplete knowledge, Journal of Environmental Policy and Planning 9, 245-262.

[30] Minutes from a meeting arranged by RUS-gruppen, Regionalt Uppföljningssystem - a working group for identification of regional indicators, Dec. 9, 2005, available at http://www.rus.lst.se/nyheter.html?id=52, accessed 12 March 2009.

[31] H. Nowotny, P. Scott, M. Gibbons (2001), Re-Thinking Science: Knowledge and the Public in an Age of Uncertainty, Polity Press, Cambridge U.K.

[32] R. Grove-White, P. Macnaghten, S. Mayer and B. Wynne (1997), Uncertain World. Genetically Modified Organisms, Food and Public Attitudes in Britain. The Centre for the Study of Environmental Change, Lancaster University, Lancaster U.K.

[33] L. Frewer, S. Miles, M. Brennan, S. Kuznesof, M. Ness and C. Ritson (2002), Public preferences for informed choice under conditions of risk uncertainty, Public Understanding of Science 11, 363-373.

[34] Swedish Environmental Protection Agency, http://www.naturvardsverket.se, accessed 7 Jan. 2009.

[35] M. Johansson (2008), Barriärer och broar. Kommunikativa villkor i det svenska miljömålsarbetet, (Diss.) Department of Water and Environmental Studies, Linköping University.

[36] D. Altheide (2004), Media logic and political communication, Political Communication, 21, 293-296.

[37] V. Wibeck (ms), Images of environmental management. Competing metaphors in focus group discussions about environmental goal achievement.

[38] K. Wahlin and A. Grimvall (2008), Uncertainty in water quality data and its implications for trend detection: lessons from Swedish environmental data, Environmental Science and Policy, 11, 115-124.

[39] T. Rogers-Hayden and N. Pidgeon (2007), Moving engagement "upstream"? Nanotechnologies and the Royal Society and Royal Academy of Engineering's inquiry, Public Understanding of Science 16, 345-364.

[40] N. Pidgeon (1998), Risk assessment, risk values and the social science programme: why do we need risk perception research, Reliability Engineering and System Safety 59, 5-15.

[41] K. Beratan, S. Kabala, S. Loveless, P. Martin and N. Spyke (2004), Sustainability indicators as a communicative tool: building bridges in Pennsylvania, Environmental Monitoring and Assessment 94, 179-191.

[42] V. Wibeck, M. Johansson, A. Larsson and G. Öberg (2006), Communicative aspects of environmental management by objectives: examples from the Swedish context, Environmental Management 37, 461-469. 
[43] T. Christensen (1991), Virksomhetsplanlegging - staffasje eller effektivt styringsverktöj, in P. Laegrid (ed.), Malstyring og virksomhetsplennlegging $i$ offentlig sektor, pp. 83-92, Bergen, Norway, Alma Mater Forlag.

[44] A. Levine (1980), Why Innovations Fail, State University of New York Press, Albany, NY.

[45] T. Busch (1998), Attitudes towards management by objectives: an empirical investigation of selfefficacy and goal commitment, Scandinavian Journal of Management 14, 289-299.

[46] P. Rodari (2008), The frontiers of dialogue, JCOM 07(01), C01.

\section{Author}

Victoria Wibeck is an assistant professor of Environmental Science, with a $\mathrm{PhD}$ in Communication Science (Linköping University, Sweden). She is currently involved in research on communication barriers in environmental management and on social representations of climate change.

E-mail: victoria.wibeck@liu.se.

How TO CITE: V. Wibeck, Communicative challenges in assessing progress towards environmental quality objectives, Jcom 08(02) (2009) A01. 